\title{
AN EVALUATION OF ROCK SLOPE STABILITY USING LIMIT EQUILIBRIUM ANALYSES
}

\author{
Faridha Aprilia and I Gde Budi Indrawan* \\ Department of Geological Engineering, Faculty of Engineering, Universitas Gadjah Mada, Indonesia
}

\begin{abstract}
The stability of rock slopes is controlled by several factors, such as the intact rock strength, discontinuity characteristics, groundwater condition, and slope geometry. Limit equilibrium (LE) analyses have been commonly used in geotechnical practice to evaluate the stability of rock slopes. A number of methods of LE analyses, ranging from simple to sophisticated methods, have been developed. This paper presents stability analyses of rock slopes at the Batu Hijau open mine in Sumbawa Barat using various methods of LE analyses. The LE analyses were conducted at three cross sections of the northern wall of the open mine using the Bishop Simplified, Janbu Simplified, Janbu Generalised, and General Limit Equilibrium (GLE) methods in Slide slope stability package. In addition, a Plane Failure (PF) analysis was performed manually. Shear strength data of the discontinuity planes used in the LE analyses were obtained from back analyses of previous rock slope failures. The LE analysis results showed that the rock slopes were likely to have shallow non-circular critical failure surfaces. The factor of safety $(F s)$ values obtained from the Bishop Simplified, Janbu Simplified, Janbu Generalised, and GLE methods were found to be similar, while the Fs values obtained from the PF method were higher than those obtained from the more rigorous methods.
\end{abstract}

Keywords: Batu Hijau mine, Bishop Simplified, Janbu Simplified, Janbu Generalised, limit equilibrium analyses, general limit equilibrium, rock slope stability, plane failure.

${ }^{*}$ Corresponding author: IG.B. INDRAWAN, Department of Geological Engineering, Faculty of Engineering, Universitas Gadjah Mada, Indonesia. E-mail: igbindrawan@ugm.ac.id

\section{Introduction}

Rock slopes may fail in various modes, such as plane, wedge, toppling, or circular failure (Hoek and Bray, 1981). Stability of rock slopes can be analysed by manual calculation employing simple equations and charts, spreadsheet software, and computer programs. LE methods have been commonly used in stability assessment of soil and rock slopes. The methods were developed based on the principles of static equilibrium (Ching and Fredlund, 1984). For rock slope stability analyses, the methods analyse the equilibrium of a potentially unstable rock mass by comparing the forces leading the rock mass to fail (i.e., driving forces, Df) along the failure surface and the forces resisting the movement of the rock mass (i.e., resisting forces $\left(R_{f}\right)$ (Figure 1 ). The ratio of $R_{f}$ to $D_{f}$ is called the factor of safety against sliding $\left(F_{S}\right)$, as formulated in Equation (1). A slope is considered to be in the state of equilibrium if the $F_{S}$ equals to 1 .

$$
F_{s}=\frac{R_{f}}{D_{f}}=\frac{R_{c}+R_{\phi}}{W \sin \psi}=\frac{c A+W \cos \psi \tan \phi}{W \sin \psi}
$$

where: $R_{c}=$ cohesion force; $c=$ cohesion of failure surface; $R=$ friction force; $\phi=$ angle of internal friction of failure surface; $A=$ rock mass area; $W=$ rock mass weight; $\psi=$ rock slope angle. A number of methods of LE analyses have been developed. The methods vary with respect to slope failure modes (plane, wedge, toppling, or circular failure) and the assumptions and equilibrium conditions adopted in order to achieve a determinate solution. Some methods consider only 


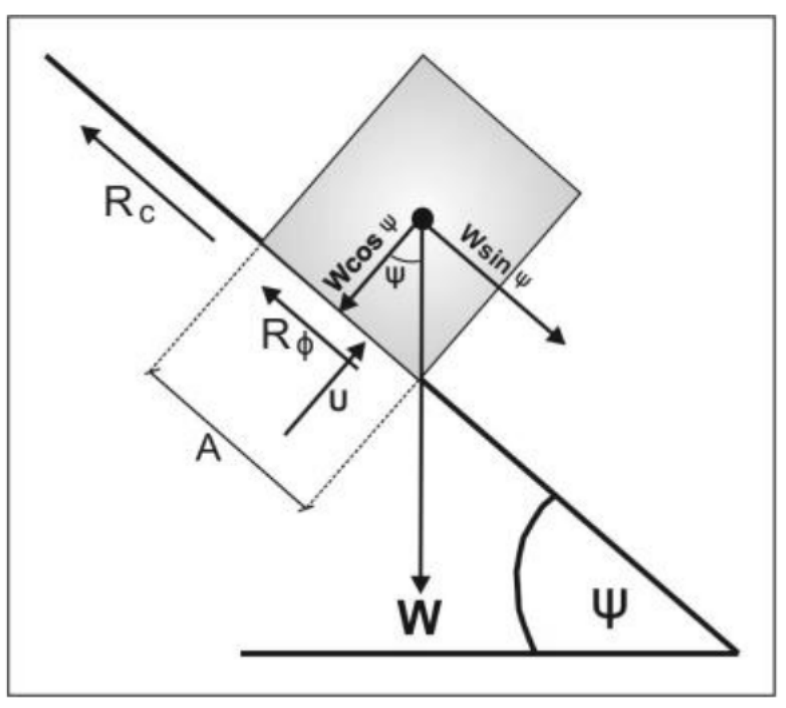

Figure 1: Forces acting on a failure surface of rock slope (González de Vallejo and Ferrer, 2011).

normal force, while the other methods consider both normal and shear forces acting on the slices. Furthermore, some methods consider only force or moment equilibrium condition, while the other methods satisfy both equilibrium conditions. The Bishop Simplified, Janbu Simplified, Janbu Generalised, and GLE methods have been commonly used in the LE analyses (e.g., Fredlund et al., 1981; Ching and Fredlund, 1984). Bishop's Simplified method is based on the moment equilibrium condition, while the Janbu Simplified and Generalised methods are based on the force equilibrium condition. The GLE method satisfies both force and moment equilibrium conditions in the formulation (Krahn, 2004). The Batu Hijau open mine is one of the largest gold and copper mines in Indonesia operated by PT. Newmont Nusa Tenggara. A number of rock slope failures due to weak rock mass condition associated with high degree of rock fractures has been occurred since the beginning of the mine operation in early 2000 (Adriansyah, 2012). Evaluation of rock slope stability is performed routinely to ensure the safety and optimum of mining activities. This paper presents stability analyses of rock slopes at the Batu Hijau open mine in Sumbawa Barat using the Bishop Simplified, Janbu Simplified, Janbu Generalised, and GLE methods. In addition, a simple LE analysis, as described in Eq.(1), called herein Plane Failure (PF) analysis, was also performed to verify whether or not a simpler LE method could result in a factor of safety as realistic as the more rigorous LE methods, which satisfied the Newtonian force principles at the interslices (Fredlund and Krahn, 1977). Results of the rock slope stability analyses using the LE methods are presented and compared and the differences between the analysis results are highlighted.

\section{Geology and rock engineering proper- ties}

The research area is mainly composed of highly fractured grey volcanic lithic breccia and quartzdiorite (Figure 2). The volcanic breccias and quartz diorite have unit weights of 27 and $26 \mathrm{kN} / \mathrm{m}^{3}$, respectively (PT. Newmont Nusa Tenggara, 2013). The geological structures developed in the rock mass in the research area are mainly northwest-southeast and northeastsouthwest oriented joints and faults, which are products of tectonic and magma intrusion (Figure 3 and Figure 4). The rock mass rating (RMR) values of the rock slopes range from 20 to 70 and are dominated by 30 to 40 (PT. Newmont Nusa Tenggara, 2013), indicating a poor rock mass quality (Bieniawski, 1989).

\section{Methodology}

The LE analyses using the Bishop Simplified, Janbu Simplified, Janbu Generalised, and GLE methods were performed in Slide slope stability package (Rocscience, Inc.). In the LE analyses, the strength of joints- and faults-filled materials, which were relatively homogenous, was modeled by Mohr-Coulomb criterion, and the strength of rock masses was modeled by the anisotropic strength function. A non-circular type of failure surfaces was assigned in all methods as kinematic analyses of discontinuity measurements in the field indicated that the rock slopes would likely not fail in a circular mode (Aprilia, 2014). The rock masses consisting the slopes were grouped into domains, where each domain represented a rock mass 


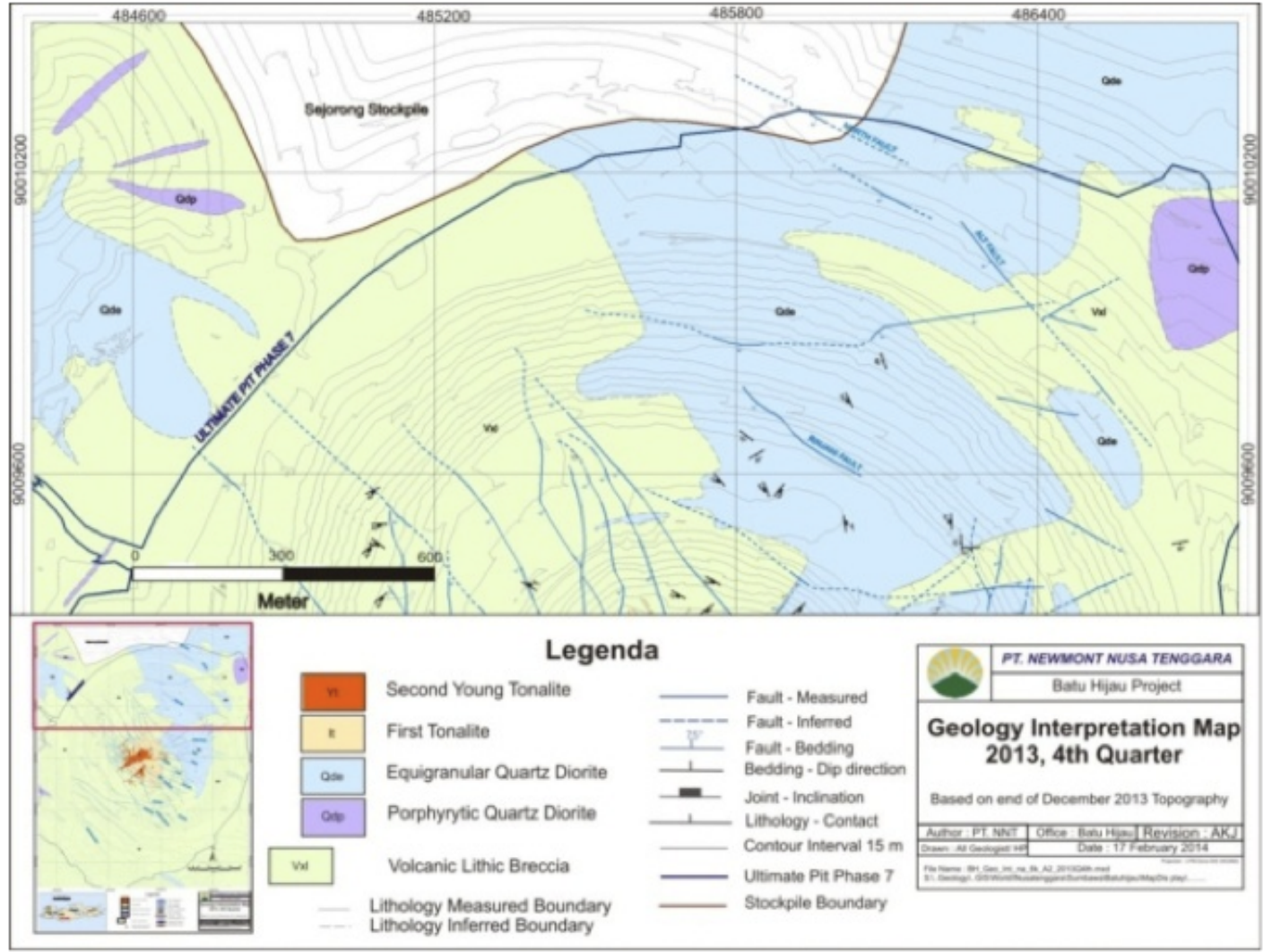

Figure 2: Geological map of research area (PT. Newmont Nusa Tenggara, 2013).

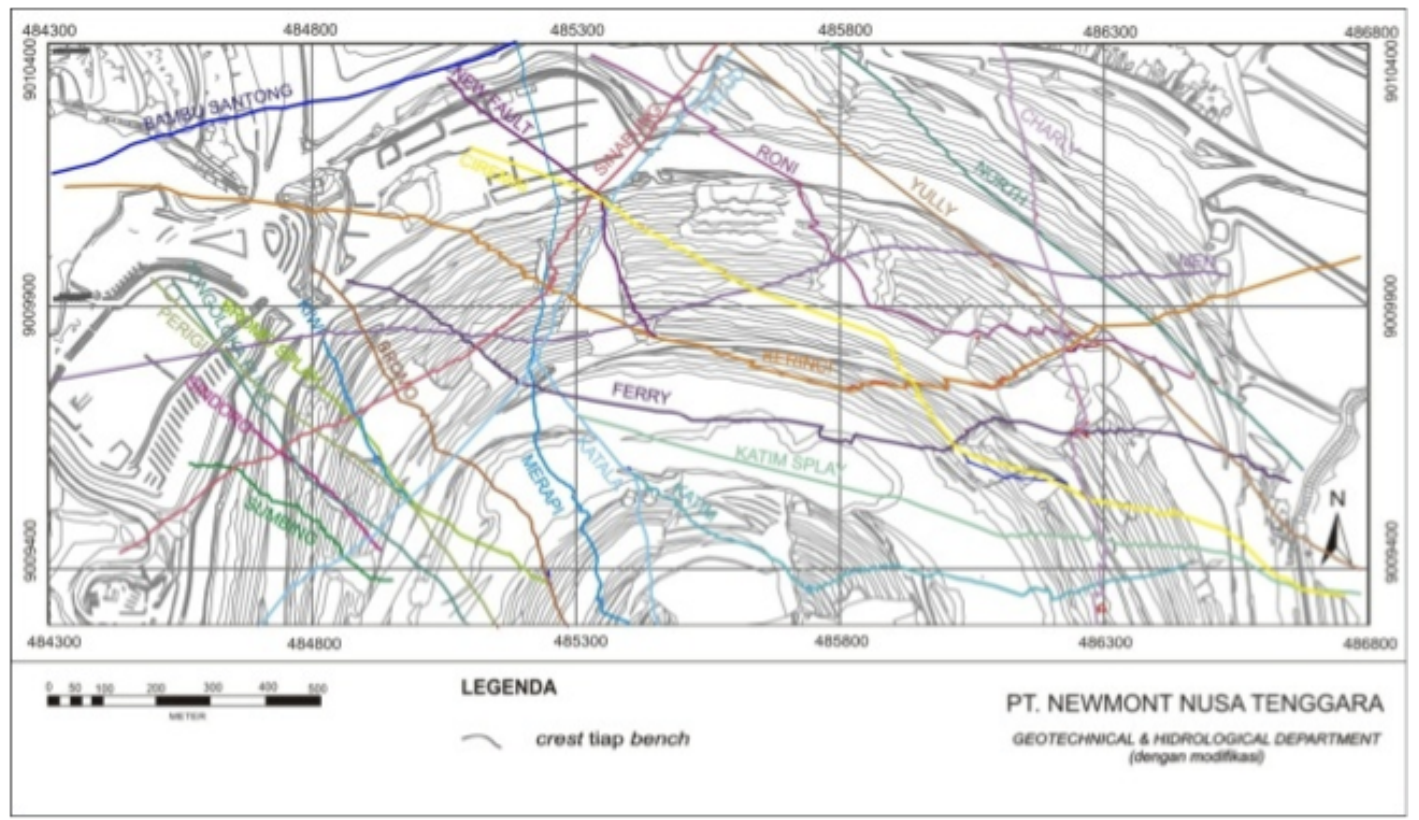

Figure 3: Major geological structures in research area (PT. Newmont Nusa Tenggara, 2013). 


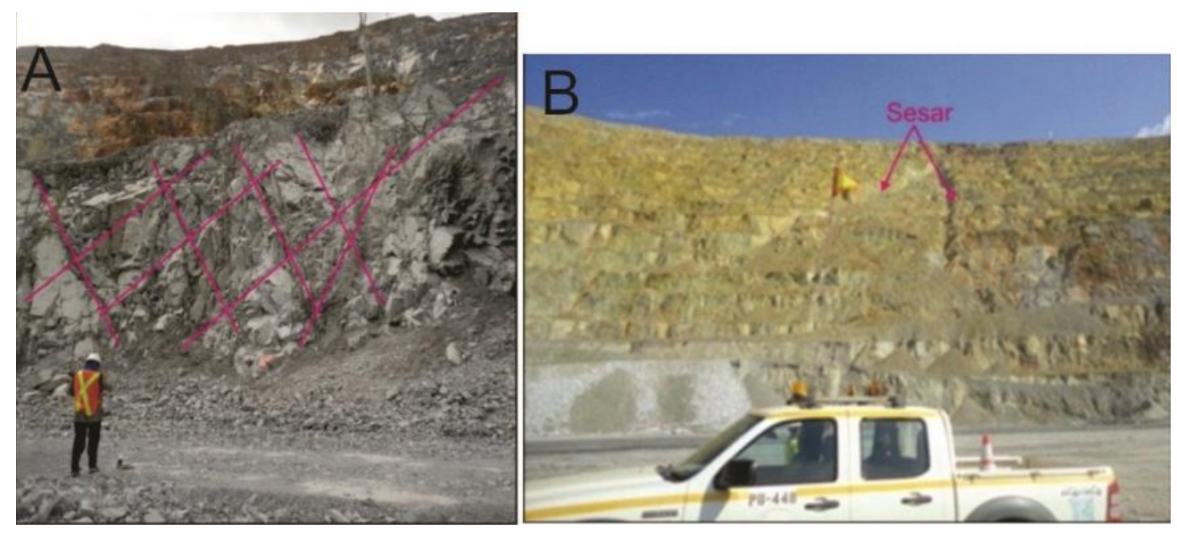

Figure 4: Joints and faults observed in research area.

having similar lithology, strength, and geologic structure. Disturbance factor $(D)$ due to blasting effects was applied to the rock masses based on the depth from the ground surface. $D$ values equal to $1,0.7$, and 0.5 were assigned for the rock masses at $0-30 \mathrm{~m}, 30-50 \mathrm{~m}$, and more than $50 \mathrm{~m}$ depths, respectively.

The LE analyses using PF method was performed manually. The $F_{s}$ was calculated by comparing the resisting forces and driving forces acting on the failure surfaces, as described in Equation (1). To facilitate the computation, the potentially unstable rock masses above the assumed failure surfaces at the all cross sections, including the rock masses above and below the ramps at the cross sections $B$ and $C$, were divided into several blocks of slices following the angles of the failure surfaces. The driving and resisting forces from rock mass blocks upslope were taken into account in the calculation of driving and resisting forces of rock mass blocks downslope. The critical failure surfaces of rock masses for LE analyses using the PF method were drawn based on those obtained from the LE analyses using the GLE method. The critical failure surfaces obtained from the Bishop Simplified, Janbu Simplified, Janbu Generalised, and GLE methods appeared to be relatively similar to each other, as presented below.

The LE analyses were performed at three cross sections A, B, and C (Figure 5). Each slope of the cross sections $B$ and $C$ is essentially divided into two parts, which are below and above the ramp. Meanwhile, the slope of the cross section A is a continuous slope without any ramp. Geometries of the rock slopes of the cross sections A, B, and C assigned for the LE analyses using the Bishop Simplified, and Janbu Simplified and Generalised, and GLE methods are shown in Figure 6, while geometry of the cross section A and typical forces acting on rock mass blocks above failure surfaces assigned in the PF method are shown in Figure 7. The cohesion $(c)$ and internal friction angle $(\phi)$ values of potential failure surfaces, which were likely controlled by existence of joints and faults in the rock mass, were obtained by performing back analyses to the previous rock slope failures F\#X1, F\#X2 and F\#X3 located near the respective cross sections (Figure 5). In the back analyses, as the faults observed in the field were typically open, the fault planes were conservatively assumed to have $c=0 \mathrm{kPa}$ and as the faults were typically filled with clay materials, the fault planes were assumed to have $\phi=20^{\circ}$, as described in Hoek and Bray (1981). The back analysis of each slope failure was performed in two steps. In the first step, the c value for the joint set was initially set to $0 \mathrm{kPa}$ to search for the $\phi$ value for the maximum $\phi$ value for the joint set when the Fs equals to 1 or close to 1 , indicating slope failure. In the second step or once the $\phi$ value for the maximum $\phi$ value for the joint set were obtained, the $\mathrm{c}$ value for the joint set was increased and $\phi$ value for the joint set was decreased until the condition of Fs equals to or close to 1 was attained. The final $c$ and $\phi$ values for the planes of the joint sets were then used in the LE analyses. 


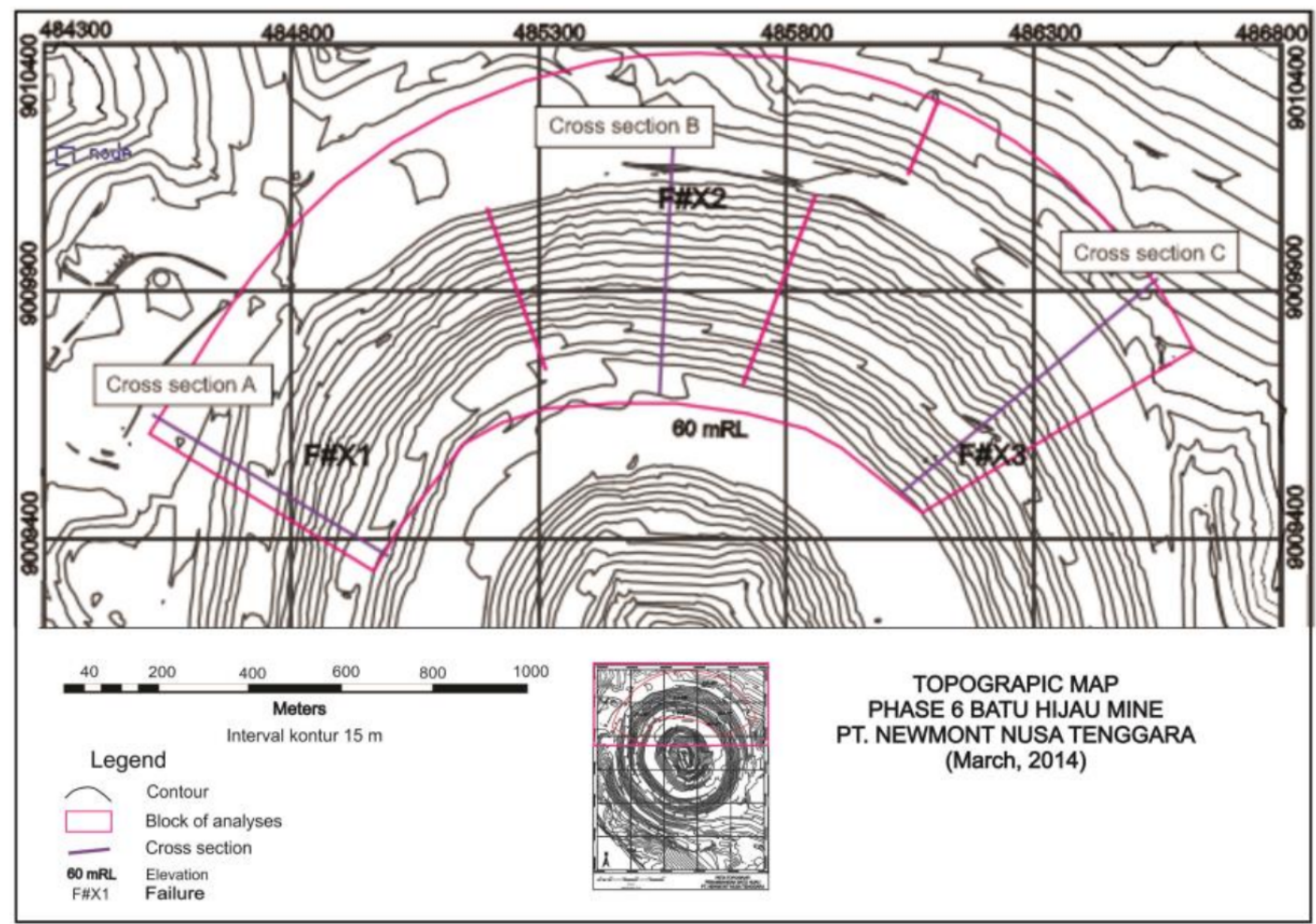

Figure 5: Locations of rock slope failures and cross sections for slope stability analyses.

The influence of pore water pressure changes due to rain water infiltration on the rock slope stability was not considered in all LE analyses. As the ground water level was considerably deep (Figure 6) and would likely not influence the calculation results, the influence of pore water pressure was not considered in the PF method. Adopting stability conditions by Priest and Brown (1983), the slopes were considered to be in equilibrium, critical, and safe conditions when $F_{S}=1,1<F_{S}<1.2$ and $F_{S} \geq$ 1.2 , respectively.

\section{Results and discussions}

Results of the back analyses of the previous rock slope failures F\#X1, F\#X2 and F\#X3 are listed in Table1. When the slopes failed, the joint planes were estimated to have $c$ values ranging from $57 \mathrm{kPa}$ to $85 \mathrm{kPa}$ and $\phi$ values ranging from $25^{\circ}$ to $27^{\circ}$. The estimated $c$ values of the joint planes that were higher than those of the fault planes were considered to be reasonable as the separation (aperture) of the joint planes was typi-
Table 1: Back analysis results of slope failures.

\begin{tabular}{|l|l|c|c|}
\hline Slope failure & Discontinuity & $\mathrm{c}\left(\mathrm{kN} / \mathrm{m}^{2}\right)$ & $\phi\left(^{\circ}\right)$ \\
\hline \multirow{2}{*}{ F\#X1 } & Joints & 85 & 25 \\
\cline { 2 - 4 } & Faults & 0 & 20 \\
\hline \multirow{2}{*}{ F\#X2 } & Joints & 60 & 27 \\
\cline { 2 - 4 } & Fault (Roni) & 0 & 17 \\
\hline \multirow{2}{*}{ F\#X3 } & Joints & 57 & 27 \\
\cline { 2 - 4 } & Fault (Ciremai) & 0 & 16 \\
\hline
\end{tabular}

cally small or was not as large as that of the fault planes.

Figure 9 to Figure 11 show LE analysis results of cross sections A, B, and C using the Bishop Simplified, Janbu Simplified, Janbu Generalised, and GLE methods. The non-circular critical failure surfaces predicted by all methods were relatively shallow (i.e., less than 30 $\mathrm{m}$ below the slope surface) and located in the uppermost layer of the rock mass domains. At the cross sections $B$ and $C$, the critical failure surfaces were developed above and below the ramps. The $F_{S}$ values for the critical failure surfaces analysed using all methods are listed in Table 2. In general, the Bishop Simplified, 

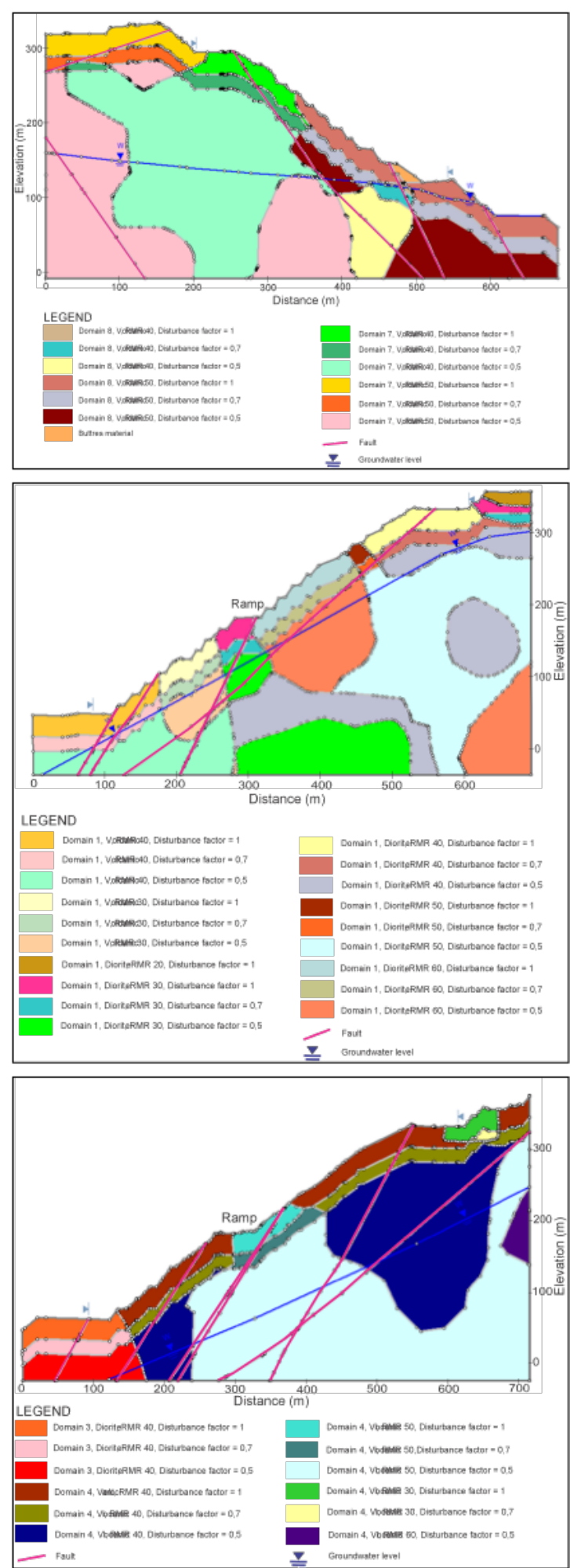

Figure 6: Geometries of cross sections A (top), B (middle), and C (bottom) assigned in the Bishop Simplified, Janbu Simplified and Generalised, and GLE methods.

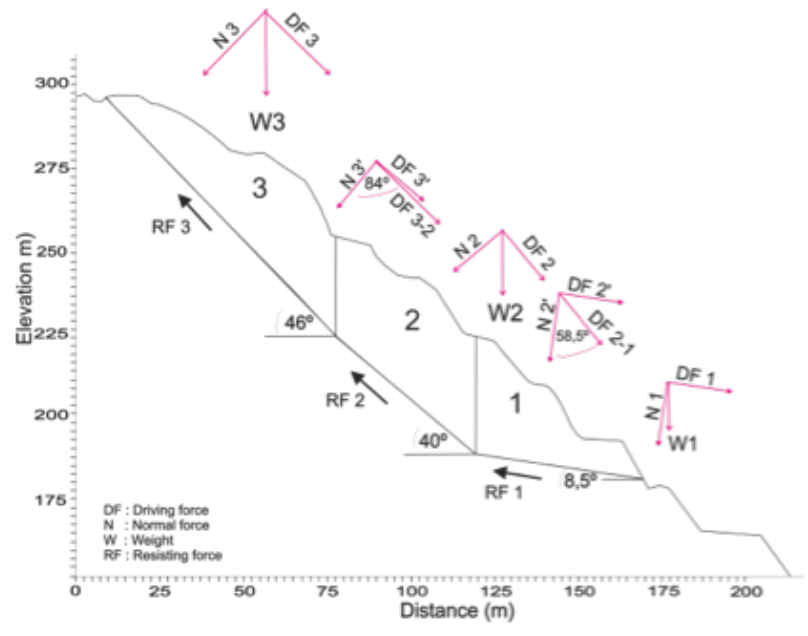

Figure 7: Geometry of cross section $\mathrm{A}$ and forces acting on rock mass blocks above failure surfaces assigned in PF method.

Janbu Simplified and General, and GLE methods resulted in similar $F_{S}$ values. This is in agreement with the slope stability analysis results obtained by Ching and Fredlund (1984), who concluded that the difference between results of slope stability analyses using Bishop Simplified, Janbu Simplified and Generalised methods were insignificant for shallow failure surfaces. As each method of the LE analyses is essentially a special case of the GLE (Fredlund et al., 1981), the $F_{s}$ values obtained from the GLE method are expected to be similar to those of the Bishop Simplified, Janbu Simplified and Generalised methods. Table 2 also shows that the PF method results in $F_{S}$ values higher than the other methods of the LE analyses. The discrepancy of the analysis results was expected as, among any others, the side forces at each slice were not considered in the PF method. The assumed failure surfaces in the PF method were likely not the critical failure surfaces (having the minimum $F_{S}$ ). Although analysis results obtained from the PF method are relatively far from those from the more rigorous methods, the PF method can be used for a preliminary assessment of slope stability.

The LE analyses using the Bishop, Janbu Simplified and Generalised, and GLE methods show that the slopes at the all cross sections had $F_{S}$ values between 1 and 1.2 and were essentially in a critical condition, according to 
Table 2: Results of LE analyses.

\begin{tabular}{|l|c|c|c|c|c|}
\hline \multirow{2}{*}{$\begin{array}{l}\text { Cross } \\
\text { section }\end{array}$} & \multicolumn{5}{|c|}{ Factor of safety (F } \\
\cline { 2 - 6 } & $\begin{array}{c}\text { Bishop } \\
\text { Simplied }\end{array}$ & $\begin{array}{c}\text { Janbu } \\
\text { Simplified }\end{array}$ & $\begin{array}{c}\text { Janbu } \\
\text { Generalised }\end{array}$ & GLE & PF \\
\hline A & 1.01 & 0.97 & 1.02 & 1.05 & 1.23 \\
\hline B (above) & 1.04 & 1.00 & 1.04 & 1.02 & 1.10 \\
\hline B (below) & 1.03 & 0.99 & 1.03 & 1.02 & 1.07 \\
\hline C (above) & 1.09 & 1.06 & 1.08 & 1.07 & 1.24 \\
\hline C (below) & 1.02 & 0.99 & 1.02 & 1.01 & 1.04 \\
\hline
\end{tabular}

the slope stability conditions proposed by Priest and Brown (1983). Although the calculation results showed that the slopes were in a critical condition, the slopes in the field appeared to be stable. The discrepancy between the analysis results and the field conditions may be partly due to the low estimated shear strength parameters (c and $\phi$ ) of the discontinuity (fault and joint) planes. More reasonable shear strength parameters obtained from direct measurements will likely result in $F_{S}$ values that are closer to the field conditions.

\section{Conclusions}

The stability of rock slopes at the Batu Hijau mine was evaluated using the Bishop Simplified, Janbu Simplified, Janbu Geralised, and GLE methods of the LE analyses. The rock slopes were likely to have shallow non-circular critical failure surfaces located in the uppermost layer of the rock mass domains. The $F_{s}$ values obtained from the Bishop Simplified, Janbu Simplified, Janbu Geralised, and GLE methods were found to be similar, while the Fs values obtained from the PF method were higher than those obtained from the Bishop Simplified, Janbu Simplified, Janbu Generalised, and GLE methods.

\section{Acknowledgement}

The research was supported by Department of Geological Engineering Universitas Gadjah Mada and PT. Newmont Nusa Tenggara. The first author wishes to thank PT. Newmont Nusa Tenggara for the opportunity to do the research. The assistance of Mrs. Adriansyah and Khatib Syarbini of Department of Geotechnical and
Hydrogeology of PT. Newmont Nusa Tenggara is gratefully acknowledged.

\section{References}

Adriansyah, Y., 2013. Prediksi Longsor Berdasarkan Data Hasil Pemantauan Pergerakan Lereng di Tambang Batu Hijau - PT. Newmont Nusa Tenggara (Studi Kasus dari Beberapa Longsoran). Seminar Nasional Geomekanika II, Peran Geomekanika dalam Pembangunan Sektor Pertambangan, Perminyakan dan Infrastruktur, Aston Primera Pasteur, Bandung, Indonesia.

Aprilia, F. 2014. Analisis Tipe Longsor dan Kestabilan Lereng berdasarkan Orientasi Struktur di Dinding Utara Tambang Batu Hijau, Sumbawa Barat. Skripsi. Jurusan Teknik Geologi, Fakultas Teknik, Universitas Gadjah Mada (unpublished).

Bieniawski, Z.T. 1989. Engineering Rock Mass Classification. John Wiley \& Sons, New York. Ching, R., K., H. and Fredlund, D.G. 1984. Quantitative Comparison of Limit Equilibrium Methods of Slices. Proceedings of the Fourth International Symposium on Landslides, Toronto, Canada, pp. 373-379.

Fredlund, D.G. and Krahn, J. 1977. Comparison of Slope Stability Methods of Analysis. Canadian Geotechnical Journal, Vol. 14, pp. 429-439.

Fredlund, D.G., Krahn, J., and Pufahl, D.E. 1981. The Relationship between Limit Equilibrium Slope Stability Methods. In Proceedings of the 10th Conference of the International Society for Soil Mechanics and Foundation Engineering (ISSMFE), Stockholm, Sweden, Vol. 3, pp. 409-416.

González de Vallejo, L. I. and Ferrer, M. 2011. 

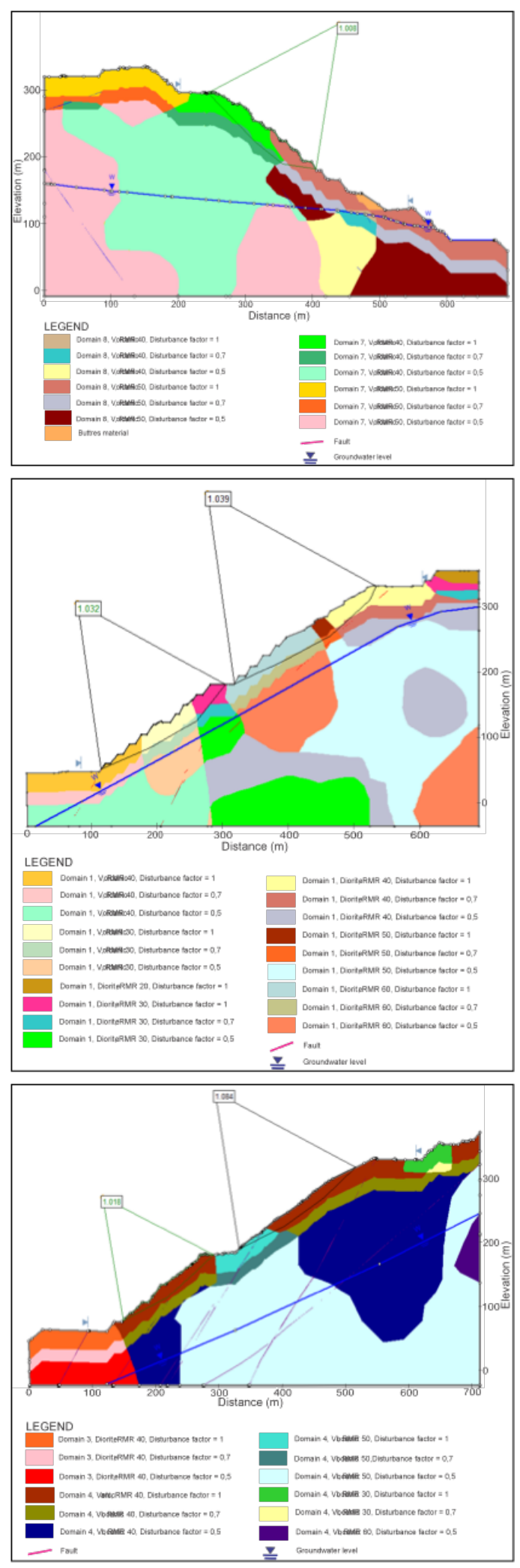

Figure 8: LE analysis results of cross sections A (top), B (middle), and C (bottom) using Bishop Simplified method.
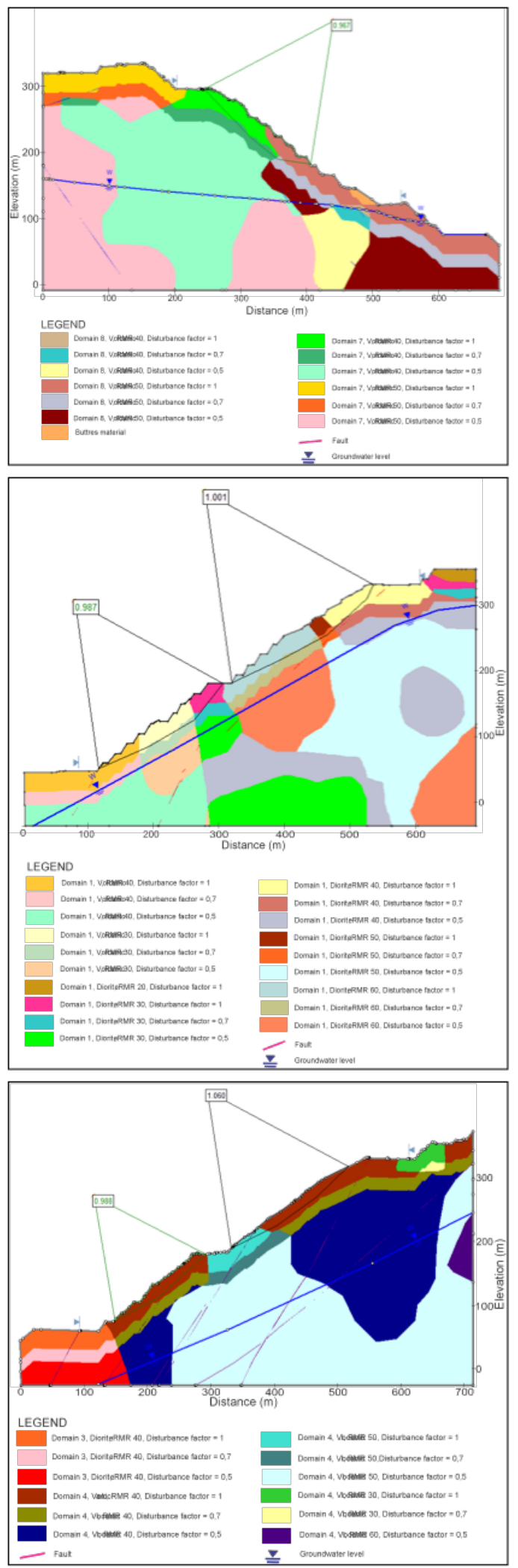

Figure 9: LE analysis results of cross sections A (top), B (middle), and C (bottom) using Janbu Simplified method. 

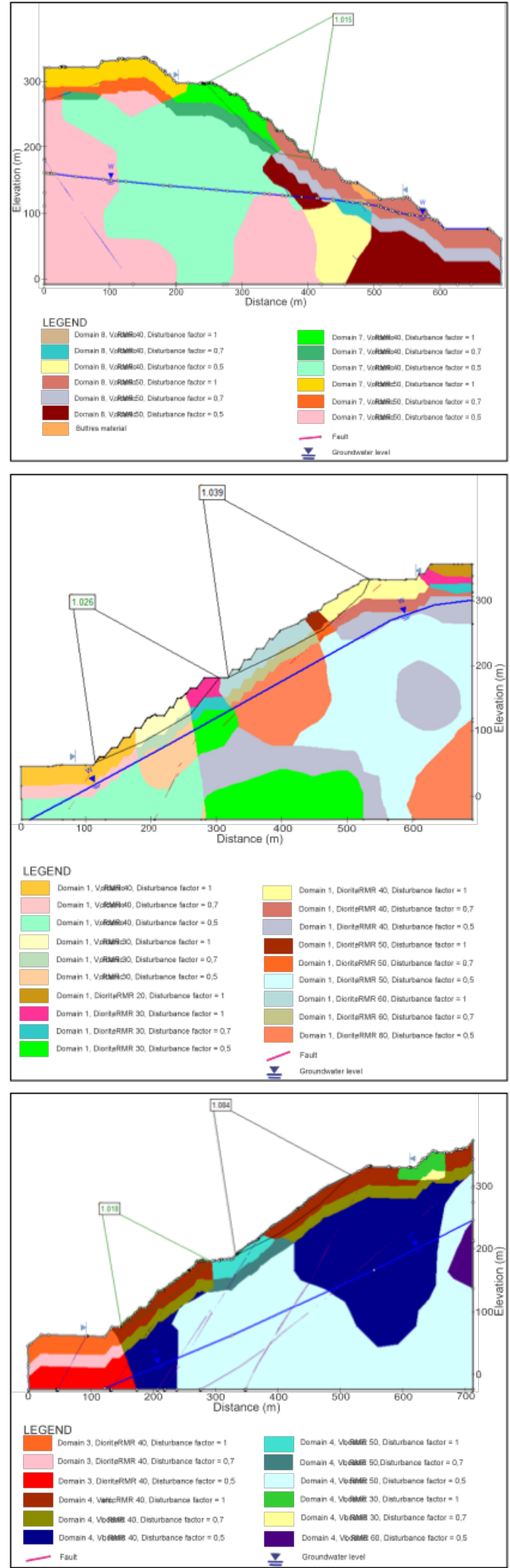

Figure 10: LE analysis results of cross sections A (top), B (middle), and C (bottom) using Janbu Generalised method.
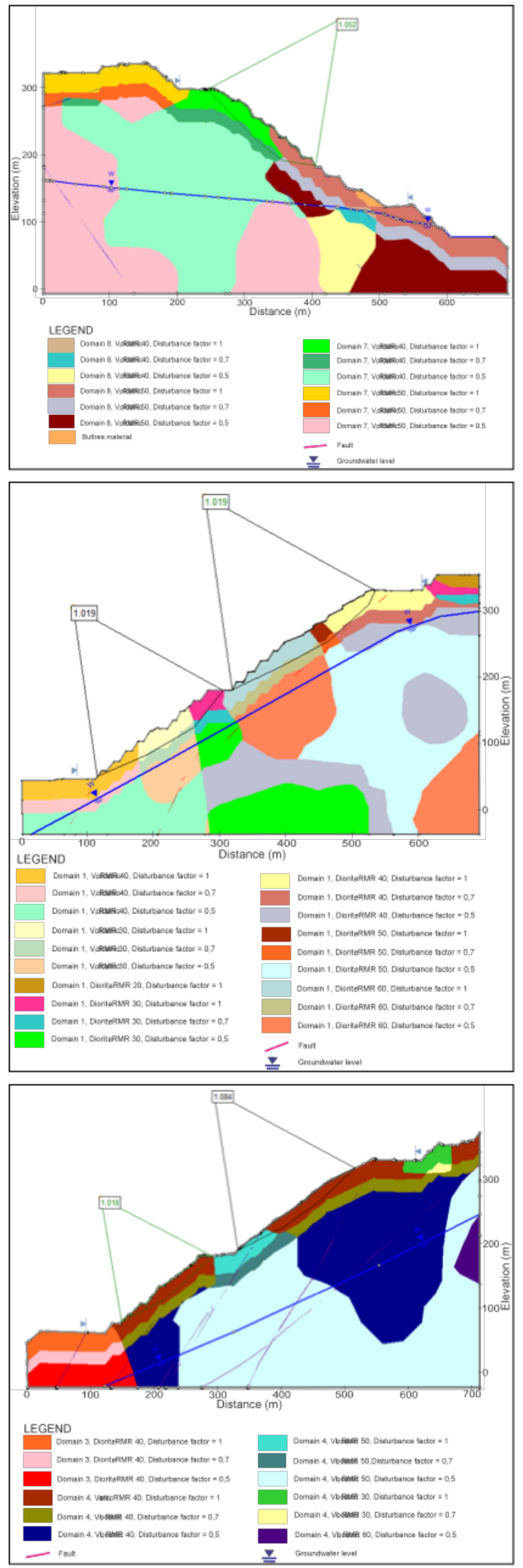

Figure 11: LE analysis results of cross sections A (top), B (middle), and C (bottom) using GLE method. 
Geological Engineering. Leiden, Netherlands: CRC Press/Balkema.

Hoek, E. and Bray, J.W. 1981. Rock Slope Engineering. 3rd Ed. The Institution of Mining and Metallurgy, London.

Krahn, J. 2004. Stability Modelling with SLOPE/W. GEO-SLOPE/W International, Ltd., Canada.

PT. Newmont Nusa Tenggara. 2013. Laporan
Intern. Departemen Geoteknik dan Hidrogeologi PT. Newmont Nusa Tenggara, Sumbawa Barat (unpublished).

Priest, S.D. dan Brown, E.T. 1983. Probabilistic stability analysis of variable rock slopes. Transactions of Institution of Mining and Metallurgy. (Section A: Mining Industry), pp. A1 - A12. 